Journal of Educational Research in Developing Areas (JEREDA)

Vol. 1. Issue 1, Pp. 57-67, Inaugural Edition, 2020

http: / / www.jeredajournal.com

E-mail: info@jeredajournal.com

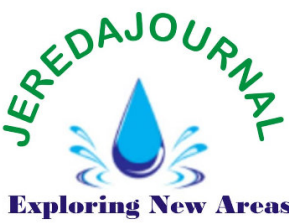

Research Article DoI: https://doi.org/10.47434/JEREDA/

eISSN : $2735-9107$

\title{
PERCEPTION AND PRACTICES OF ACTION RESEARCH BY PROSPECTIVE TEACHERS IN TEACHER EDUCATION INSTITUTIONS IN PAKISTAN
}

\section{${ }^{1}$ Nadia Parveen Thalho, ${ }^{2}$ Yakubu Doris Gomos}

\author{
${ }^{1}$ Department of Education and Social Sciences, \\ Iqra University, Karachi, Pakistan. \\ thalhonadia786@gmail.com \\ (ii) https://orcid.org/0000-0003-3728-4273 \\ ${ }^{2}$ Department of Special Education \& Rehabilitation Sciences, \\ University of Jos, Nigeria
}

Received: $22^{\text {nd }}$ August, 2020; Revised: $30^{\text {th }}$ August, 2020; Accepted $03^{\text {rd }}$ September, 2020

\begin{abstract}
Introduction: Action research plays a key role in teacher education; the simple aim of this research was to discover the perception of action research by prospective teachers, which was also part of the training programme. Prospective teachers self-analyze the problems of their students and provide a solution while working in their schools.

Purporse: The purpose of this study was to analyze the perception and practices of prospective teachers during the course of action research in teacher education institutions, B.Ed Hons Programme.

Methodology: This research was a cross-sectional survey. The researchers adopted the deductive method of research. Quantitative approach was used for data collection, and sampling techniques were purposive and convenience sampling techniques in collecting data from two districts (Hyderabad and Karachi), one college was selected from each school. The researchers selected samples of 55 prospective teachers who passed B.ED Hons. Results: The findings revealed that there were little or no mean difference between the prospective students' perceptions on planning and process, importance, likeness, and abilities, assessment and supervision, and time/placement of both teacher education institution of Hyderabad and Karachi towards quality action research. The finding also revealed that prospective teachers faced problems of supervising teachers because they had no skills and methods of teaching in those institutions.

Recommendations: It is recommended that teacher educators and research coordinators should play a key role in this field, working as mentors to develop interest, create a learning environment and make use technology to impact action research on prospective teachers
\end{abstract}

Keywords: Action Research, Perception, Practices, Prospective Teacher, Education

\section{Cite paper as:}

Crossref Thalho, M. P., \& Gomos, Y. D. (2020). Perception and practices of action Cited-by research by prospective teachers in teacher education institutions in Pakistan. Journal of Educational Research in Developing Areas, 1 (1), 57-67. https://doi.org/10.47434/JEREDA.1.1.2020.57

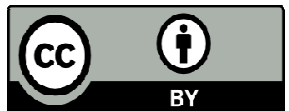

Copyright (c) 2020 The author(s) of this article retain(s) the copyright.

\section{PUBLIC INTEREST STATEMENT}

The study will especially help the teachers, and other stakeholders in improving their performance and ability to solve classroom problems and decision making. Action research will help teachers identify their problems and given critical output/result for the institutions they work with. Also, the outcome of the study will enable teachers create a platform for continuously grooming self, through the challenges and problems of the classroom. Volume 1, Number 1 (Inaugural Edition) 
Teachers and head of the department (Principal) must know the solution of such problem which may be intentionally developed in classroom environment, and this whole process is helpful for the students' learning process. By applying action research, the teachers will not only learn the needs of students, and colleagues, but will also come to know him or her problems and the strategies to overcome the problems.

\section{INTRODUCTION}

The Government of Pakistan is desirous of both quality education and teachers, where they have designed the 10 National Professional Standards for Prospective Teachers that are needed for the 21st Century Teachers (skill, disposition, and value), that will bring change in the teaching practice. The ten standards for teaching have been set out in the instructions to achieve the necessary goals. The Government of Pakistan is eager to refine the value of education that is influenced by the value of teacher education. National Professional Standards for Teachers (NPSTs) have been developed to improve the value of teachers. They were established in February 2009 by Policy and Planning Wing, Ministry of Education, Government of Pakistan, with the technical support of UNESCO and financial support of USAID (Saifulla, Sherzaman, Ali, Idrees \& Zaman, 2013), which includes the Professional Standards for Teachers (NPSTs).

The historical background of teacher education represents the initial provision of vocational education for junior vernacular (JV) and senior vernacular (SV) courses at that time. With the passage of time, these 1 -year courses were replaced by (PTC) and (CT) continued until 2008-2009. It went along with the Oriental Teaching Certificate (OTC), the Art Teaching Certificate (ATC) and the Art Master Certificate (AMC). Teacher Education Institutions have been proposing an Associate Degree in Education (ADE) since 2009 to replace PTC and CT courses in accordance with the 2009 National Education Policy. In 2015, Teacher Education also introduced the B.Ed. (Hons.) programme. The elementary programme has also been introduced, where preservice, in-service education and cocurricular activities are supported. It is also the government's responsibility to provide teachers with capacity building and to provide supervision where the Bureau Curriculum and Extension Wing, Jamshoro Volume 1, Number 1 (Inaugural Edition)
Sindh (BCEWS) now Directorate of Curriculum Assessment and Research)/Teachers Training Institution (TTI) cooperates with various stakeholders, that is the Provincial Institute of Teacher Education (PIT). After the 18th amendment, the TTI Institute has been authorised to work for all Teacher Education Institutions. It also offered inservice training for the capacity-building of teachers, teacher educators and head coaches, illuminating control staff, and side-by-side education managers. (Prospectus: GECE Karachi, 2017-2018).

In order to highlight the importance of education, the B.Ed. Hons Programme has been revised for 4 years as prospective teachers capable of exploring new teaching practices as well as meeting the national most professional standards of teachers (Mahmoud \& Iqbal, 2018; NPST, 2009). In light of the reference, fresh and new education policies were developed following the 18 amendments adopted by the Pakistan Constitution in the National Assembly. New trends in education planned for the 21st century and focused on the needs of Pakistan's society and social structure (NEP, 2017). For the last 20 years, teachers have given more importance to research in the field of education. In recent times, teachers have significantly worked to develop their educational area for constructive reflection by improving knowledge in their context, where they have adopted research to improve their work (Clarke, 2006). Action research plays a key role in improving the ability of teachers to solve problems of the classroom and introduces them as professionals in the field (Whitehead, 2002).

The present study reflected Teacher Education Institutes, while prospective teachers are pursuing action-oriented research for futuristic academic improvement and problem-solving based on their own value and interests. The Higher Education Commission has recently 
launched a new ADE/B.Ed Hons programme, full of new trends, new methodologies and well designed National Standards (NPST) for prospective teachers. This programme, initiated by the Government of Pakistan (HEC) has introduced a new curriculum, the main objective of which is to replace the teachercentered approach of teacher-training institutes and to enhance the professional skills of teacher-trainers by means of new pedagogies, motivations, workshops etc. Action Research Approach collaboratively, diagnosed by Lankshear and Michele (2004), said that approach could be justified, and in that approach, we used two terms: the first term reflects that teachers are self-reflected in that class, faced with new challenges; and second term reflects that teachers reflect their teaching practices in the field of study (Lankshear \& Knobel, 2004).

Here, the conceptual framework used for the analysis of the quality of action research by the perception and practice of teacher educators and prospective teachers is further divided into independent variables: importance, resemblance, skills and practice; planning, training (of teacher educators), supervision, assessment and placement. There are so many different models of action research that represent the quality of action research. Andrew (2012) defined dependent variable in research as the one that determines the effect of an independent variable, which focuses on the research interest, results that have changed as a result of the study during the experiment. The independent variable is measured, influenced or selected by the researchers to control its relationship to the observed variable that affects the dependent variable.

The subject of action research is recognized by different names such as: participatory, collaborative, analytical, learning, reflective practice, exploratory, self-assessment, teacher research, practice analysis, consultant, research, Biratu's (2016) word of action research also differs from time to time, as highlighted in the development of school activities and practices. In addition, the author specified that the term action research has begun to be considered as an applied and practical way to observe one's own self-exercise. Action research involves experts in thinking about and reflecting on their work. In addition, they indicated that action research is a process in which teachers examine self-practice and teaching and learning in order to develop learning for their students. In addition, Steele's (2007) action to improve the quality of education and help achieve learning objectives also included helping teachers to become masters, helping experts to solve the problems of their students and helping learners to understand the difficulties of learning through training strategies used in action research. Teacher action research has helped them to self-reflect in teaching. According to Noffke, three rationales were discussed for motivating teachers to carry out action research easily. In the first place, teachers carry out action research according to their context. Second, provide information to teachers, as well as help teachers in the institutions. This motivation helps to create equality and justice for teachers that some teachers willingly share and contribute to the development of the school environment and through social interaction (Noffke, 1997).

According to Ferrance (2000), action research could be a useful search for instructors on five grounds. These include: school problems, professional development of teachers, mutual collaboration, the ability to influence school changes, practice reflection and improved interaction. Auriacombe (2015) stated that the main purpose of the gap between understanding theory and practice is research on real issues/world in order to get the right answers. In this context, not only the problem-solving, but also the effect on human learning that reflects the ways of critical thinking and problem solving. In order to bridge the gap between career and quality of service, HEC has given greater importance to the ADE/B.Ed Hons programme in elementary schools to enhance skills through the practice and teaching of prospective teachers (Scheme of Studies, 2012).

\section{STATEMENT OF THE PROBLEM}


The prospective teachers have been confronted with problems during the conduct of action research in their respective teacher education institutions. The supervisors have no mutual understanding with the students on knowledge to convey instructions of the research project to all prospective teachers, where it is observed that prospective teachers face the problems of inadequate knowledge of the subject matter and skills. It also reported that prospective teachers face difficulties in teaching practicing centres different from what they are taught in the classroom (Yıldız, Gecikli, \& Yesilyurt, 2016). During the research, the behaviour and response of school children was different from that of prospective teachers, so they experienced difficulties in conducting research (Maksimovic, 2010).

\section{THE PURPOSE OF THE STUDY}

The aim of the study was to:

1. Find the mean difference between the prospective students' perceptions on importance of the two institutes towards quality action research.

2. Find the mean difference between the prospective students' perceptions on likeness and ability of the two institutes towards quality action research.

3. Find the mean difference between the prospective students' perceptions on planning and process of the two institutes towards quality action research

4. Find the mean difference between the prospective students' perceptions on supervision and assessment of the two institutes towards quality action research

\section{RESEARCH QUESTIONS}

1. What is the mean difference between the prospective students' perceptions on importance of the two institutes towards quality action research?

2. What is the mean difference between the prospective students' perceptions on likeness and ability

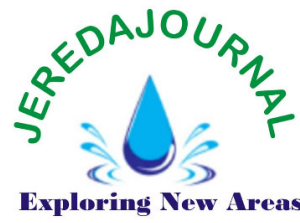

of the two institutes towards quality action research?

3. What is the mean difference between the prospective students' perceptions on planning and process of the two institutes towards quality action research?

4. What is the mean difference between the prospective students' perceptions on supervision and assessment of the two institutes towards quality action research?

\section{RESEARCH METHOLOGY \\ Research Design}

This research was designed to explore the impact of action research among the prospective education teachers. This research was carried out in a crosssectional form, which was limited but rich in text (Noddings, 2018). The researchers focused on the deductive method of research. Based on the review of the related material and literature, a research approach was developed on the quantitative method approach. The research dentified independent variables in perception (importance, likeness and capacity) and practice (planning and processing, oversight and assessment, time/ placement) all studies are based on a single dependent variable to maintain the quality of teaching action research.

\section{Population and Samples}

The sample was determined by means of a convenient and purposive sampling techniques, in which prospective teachers and teacher educators were selected from two government colleges of education in Sindh, selected for study between two institutes on the basis of action research, and the main reason for comparison was that the affiliated universities were homogenous. It was very difficult to gather data from past students, where the researchers were able to collect data with the help of the Head of Department and teachers. The prospective teachers in B.ED Hons programme (8th Semester) in Government Schools of Education were (Male $=5 \quad(9.1 \%)$ and Females $=50(91 \%)$. 
Journal of Educational Research in Developing Areas (JEREDA)

Vol. 1. Issue 1, Pp. 57-67, Inaugural Edition, 2020

http: / / www.jeredajournal.com

E-mail: info@jeredajournal.com

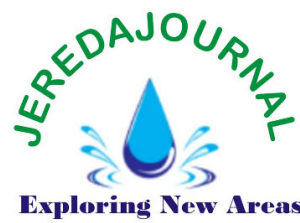

Table 1: Demographic Presentation of Participants

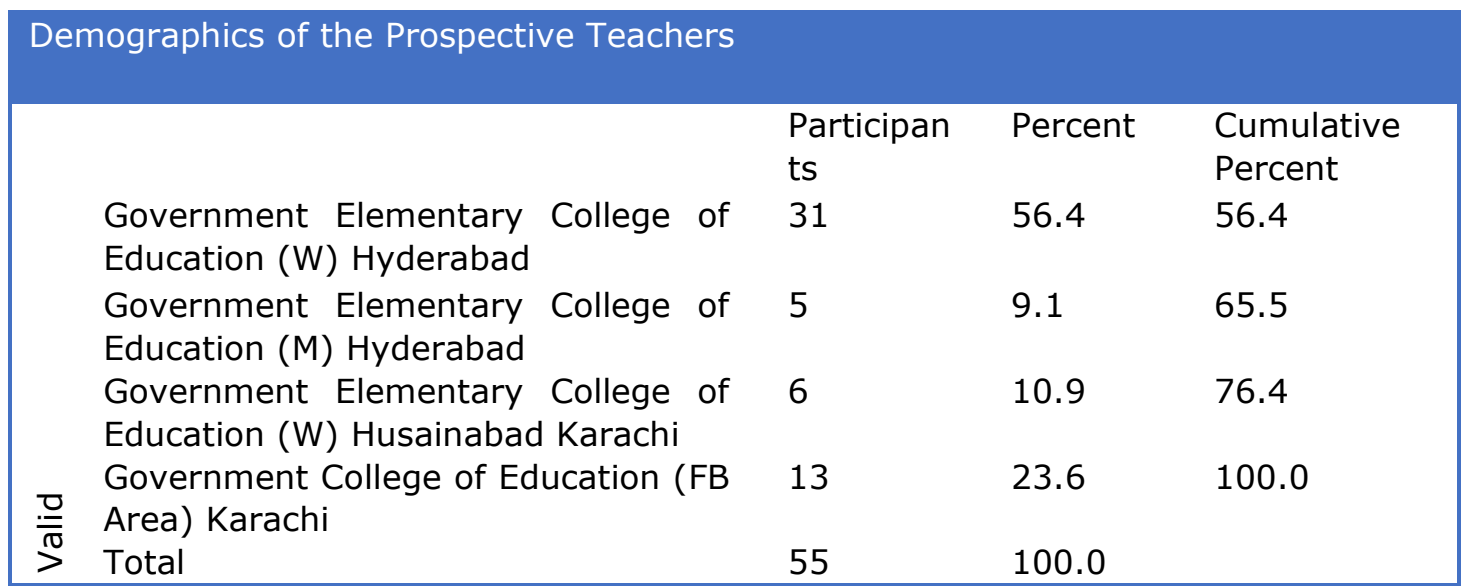

\section{Intrument for Data Collection}

Before running a factor analysis software, outliers for generalized results were removed and 55 prospective teachers' information was finalized. A Kaiser-MeyerOlkin (KMO) was used to calculate the samples that the value of $\mathrm{KMO}$ is greater than > 0.50 (Kaiser, 1974). This indicates that each factor has enough items to make factors (Leech, Barrett, \& Morgan, 2005). The Bartlett test should be significantly less than $(p<0.05)$ for an appropriate analysis of the factors. The KMO test value is well analyzed in .638, and the result was shown to be adequate, also the value of 0.000 of Bartlett's Test that the indicated matrix is not identical (Bartlett, 1950).

The reliability of the tool was measured by SPSS for the reliability of the items (Likert scale) used by the researchers. The average score corresponding to other items was analyzed. Items (28) are intended for prospective teachers and, during the analysis, the reliability was > 0.05 (Cronbach, 1951). The Cronbach Alpha of prospective teacher tools was 0.754 . Correlations between perception (importance and likeness/ability) and variable practices (planning and process, monitoring and assessment and placement/time) were calculated. The Pearson correlation is normally used in conjunction with the data (bi-variant correlation) where the two correlation coefficients measured with +1 or- 1 and mostly used. Positive relationships indicate strong correlation (Patrick, Boer, Christa; Volume 1, Number 1 (Inaugural Edition)
Lothar, \& Schwarte, 2018) using the IBM SPSS Statistic 22.

\section{Procedures for Data Collection}

The whole data was analyzed step by step where the Missing Value Analysis is a major part of the data analysis where the researchers must be conscious of analyzing the missing value whether or not it exists in the statistical data. The researchers worked on the IBM SPSS statistical programme and assured that no missing value of the prospective teachers questionnaire was left blank to collect the data. Outliers are often defined as the interpretation of data that are mostly different or different from other cases in the sample (Osborne, \& Overbay, 2004).

This study was conducted in selected institutions where a limited number of prospective teachers (55) were selected. However, for better results and simplifications, outliers have been removed at three different stages of relationship building. In the first stage, outsiders were removed while creating a relationship between perception and practice, with importance, resemblance, and ability as facilitators. In the second stage, outliers were removed in order to establish a generalized difference between practice through assessment and supervision and time / place to maintain the quality of action research. The removal of outliers may affect the size of the prospective teachers sample and make it insufficient for a positive factor analysis. Therefore, in $61 \mid \mathrm{P}$ a g e 
Journal of Educational Research in Developing Areas (JEREDA)

Vol. 1. Issue 1, Pp. 57-67, Inaugural Edition, 2020

http: / / www.jeredajournal.com

E-mail: info@jeredajournal.com

order to maintain a good KMO value ( $>$ $0.5)$ the outliers were removed separately before the factor analysis of each questionnaire. The study samples were determined by means of a convenient and objective sampling technique, where prospective teachers and educators were selected from two government colleges of education in Sindh.

\section{Method of data analysis}

There are different research questions which are sequentially discussed below. In order to answer the stated

research questions, the researchers used the mean and standard deviation to measure the difference between the two educational groups. The mean difference controls the numerical values which are different in relation to the population means (GuideLibrary, 2019).

\section{RESULTS}

Research Question 1: What is the mean difference between the prospective students' perceptions on importance of the two institutes towards quality action research?

Table 2: Mean difference of students' perceptions on importance of two Groups

\begin{tabular}{llllll}
\hline Group Stat: & & $\mathbf{N}$ & Mean & $\begin{array}{l}\text { Std. } \\
\text { Deviation }\end{array}$ & $\begin{array}{l}\text { Std. } \\
\text { Mean }\end{array}$ \\
\hline $\begin{array}{l}\text { Perception: } \\
\text { Importance }\end{array}$ & $\begin{array}{l}\text { Government college of } \\
\text { Educations Hyderabad Sindh }\end{array}$ & & 3.26 & .554 & .093 \\
& $\begin{array}{l}\text { Government college of } \\
\text { Educations Karachi Sindh }\end{array}$ & & 3.44 & .598 & .137 \\
\hline
\end{tabular}

The prospective teachers of Government college of Educations Hyderabad $(\mathrm{N}=36)$, where the mean value is 3.26 (Std.Dev: .554) which is almost similar to the mean value of prospective teachers of Government college of Educations Karachi $(\mathrm{N}-19)$, where the mean value 3.44 (Std Dev: .598). From both groups statistics, they show that the quality of action research has equal importance for the students of both Instituttes.

Research Question 2: What is the mean difference between the prospective students' perceptions on likeness and ability of the two institutes towards quality action research?

Table 3: Mean difference of students' perceptions on likeness and ability of two Groups

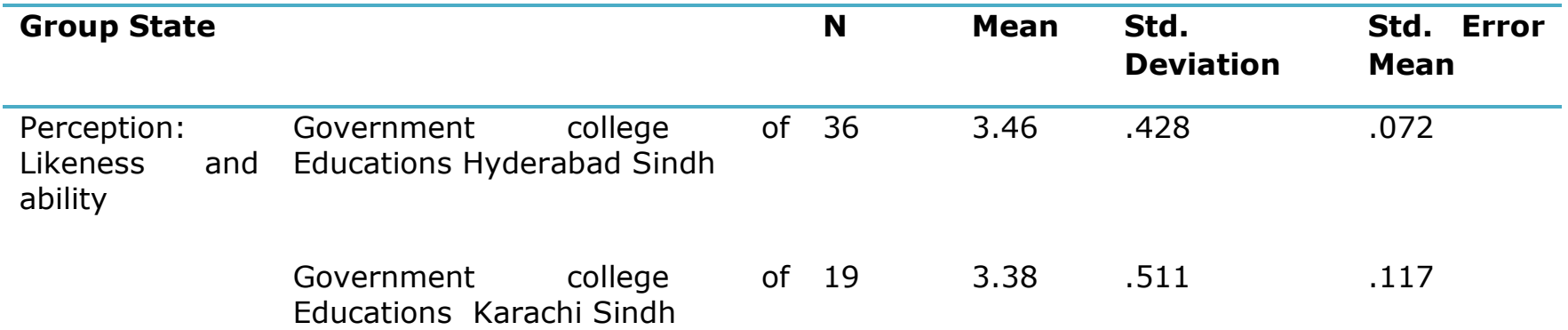

The prospective teachers of Government college of Educations Hyderabad $(\mathrm{N}=36)$, where the mean value is 3.46 (Std Dev: .428), which is almost similar to the mean value of Prospective teachers of Government college of Educations Karachi (N-19), where the mean value 3.38 (Std Dev: .511). From both groups, the statistics show that the quality of action research has equal likeness and 
Journal of Educational Research in Developing Areas (JEREDA)

Vol. 1. Issue 1, Pp. 57-67, Inaugural Edition, 2020

http: / / www.jeredajournal.com

E-mail: info@jeredajournal.com

abilities of the prospective teachers of both Institutes.

Research Question 3: What is the mean students' perceptions on planning and process of the two institutes towards quality action research?

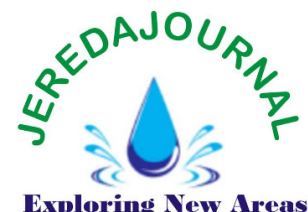

Exploring New Areas

difference between the prospective

Table 4: Mean difference of students' perceptions planning and process of two Groups

\begin{tabular}{|c|c|c|c|c|c|}
\hline \multicolumn{2}{|c|}{ Group Stat } & \multirow{2}{*}{$\begin{array}{l}\mathbf{N} \\
36\end{array}$} & \multirow{2}{*}{$\begin{array}{l}\text { Mean } \\
3.590\end{array}$} & \multirow{2}{*}{$\begin{array}{l}\text { Std. } \\
\text { Deviation } \\
.432\end{array}$} & \multirow{2}{*}{$\begin{array}{l}\text { Std. Error } \\
\text { Mean } \\
.072\end{array}$} \\
\hline \multirow{3}{*}{$\begin{array}{l}\text { Practices: } \\
\text { Planning } \\
\text { and } \\
\text { Process }\end{array}$} & Government college of & & & & \\
\hline & $\begin{array}{l}\text { Educations Hyderabad } \\
\text { Sindh }\end{array}$ & & & & \\
\hline & $\begin{array}{l}\text { Government college of } \\
\text { Educations Karachi } \\
\text { Sindh }\end{array}$ & 19 & 3.618 & .428 & .098 \\
\hline
\end{tabular}

\begin{tabular}{|c|c|}
\hline $\begin{array}{l}\text { The prospective teachers of } \\
\text { Government college of Educations } \\
\text { Hyderabad }(\mathrm{N}=36) \text {, where the mean value is } \\
3.590 \text { (Std Dev.: } .432 \text { ), which is almost }\end{array}$ & $\begin{array}{l}\text { research. From both groups, the statistics } \\
\text { show that the quality of action research has } \\
\text { equal planning and process for the students } \\
\text { of both institutes. }\end{array}$ \\
\hline $\begin{array}{l}\text { similar to the mean value of prospective } \\
\text { teachers of Government college of } \\
\text { Educations Karachi (N-19), where the mean } \\
\text { value is } 3.618 \text { (Std Dev.: .428). This shows } \\
\text { that prospective teachers at both institutes } \\
\text { value the planning and process for action }\end{array}$ & $\begin{array}{l}\text { Research Question 4: What is the mean } \\
\text { difference between the prospective students' } \\
\text { perceptions on supervision and assessment } \\
\text { of the two institutes towards quality action } \\
\text { research? }\end{array}$ \\
\hline
\end{tabular}

Table 5: Mean difference of students' perceptions on supervision and assessment of two Groups

\section{Group Statistics}

\begin{tabular}{|c|c|c|c|c|c|c|c|}
\hline Districts & & & $\mathbf{N}$ & Mean & $\begin{array}{l}\text { Std. } \\
\text { Deviation }\end{array}$ & $\begin{array}{l}\text { Std. } \\
\text { Mean }\end{array}$ & Error \\
\hline $\begin{array}{l}\text { Practices: } \\
\text { Supervision } \\
\text { and }\end{array}$ & $\begin{array}{l}\text { Government } \\
\text { Educations } \\
\text { Sindh }\end{array}$ & $\begin{array}{c}\text { college of } \\
\text { Hyderabad }\end{array}$ & 36 & 3.537 & .486 & .081 & \\
\hline
\end{tabular}

$\begin{array}{lllllll}\text { Government college of } & 19 & 3.438 & .648 & .148\end{array}$

Educations Karachi Sindh

The prospective students of Government college of Educations Hyderabad $(\mathrm{N}=36)$, where the prospective students of Government college of Educations Hyderabad $(\mathrm{N}=36)$, where mean values are. 3.537 (Std.Dev: .486) which is almost similar to the prospective students of Government college of Educations Karachi whose total students are (N-19), where mean value 3.438 (Std Dev: .648). This shows that prospective teachers at both institutes value supervision and assessment. From both groups, the statistics show that the quality of action 
Journal of Educational Research in Developing Areas (JEREDA)

Vol. 1. Issue 1, Pp. 57-67, Inaugural Edition, 2020

http://www.jeredajournal.com

E-mail: info@jeredajournal.com

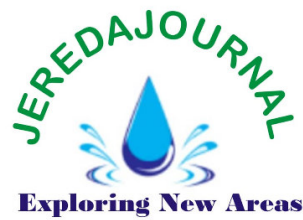

research has equal supervision and assessment on the students of both Institutes.

\section{DISCUSSION}

The study found that the perception (importance) of action research has no or little significant mean difference in the students of both institutions. This has shown that the perception of importance is one of the key factors in maintaining the quality of research action in the undergraduate programme. The study also found that the ability and resemblance of prospective teachers during the course of action research assumed to have the same mean difference. The findings were consistent with Disharoon's (2003) view that action research would help teachers identify their problems and provide the institutions with a critical output/result. Equally, the teacher has created a platform for continuous self-care, through the challenges and problems of the classroom. Teacher and Head of Department (Principal) must be aware of the solution to this problem, which is intentionally developed in the classroom environment (Mills, 2007), and this whole process is useful for students' learning, where teachers reflect the ability of a problem solver for students (Darling-Hammond, 2006). By applying research, the teacher has not only learnt the needs of students, colleagues, but also came to know his/her problems and strategies to overcome them (Ferrance, 2000).

According to the perspective of the author on action research, the author stated that action research is beneficial and assumed that teachers have been helped to make self-decisions related to their own practices, and that they have the authority to resolve issues related to their classrooms in order to improve educational outcomes (Zeichner, 2003). Action research involved experts in thinking about and reflecting on their work. In addition, they indicated that action research is a process in which teachers examine self-practice and teaching and learning in order to develop learning to their students (Biratu, 2016). In addition, Steele's (2007) action to improve the quality of education and help achieve Volume 1, Number 1 (Inaugural Edition)

learning objectives also included helping teachers to become masters, helping teachers to solve the problems of their students and helping learners to understand the difficulties of learning through training strategies in the use of action research.

The study also found that there is no significant mean difference between prospective teachers' planning and the process on the quality of action research. The findings have shown that the practices (planning and process) of action research have little or no mean difference with the students of both institutions. This has shown that the perception of planning and process is one of the key factors in maintaining the quality of action research in the undergraduate program. This was in agreement with Creswell (2005) that action research reflected self-critical and teambased research by teachers, which enhances decision-making skills and improvement through continued professional development. Bryman (2008) also stated that the school environment is affected by social interactions that reflect human behavior. In addition to being diagnosed with action research using mixed methods to solve any problems, teachers used appropriate methods for teaching practices and achieve learning objectives through action research and planning. Lydia (2015) noted that action research included planning, acting, observing and reflecting new learning strategies. Action research has so many models and approaches that express their own communication in different ways of reviewing the situation and providing solutions through discussion.

The present study has shown that there is no significant mean difference between prospective teacher supervision, assessment on the quality of action research. The study showed that the practices (supervision and evaluation) of action research have an equal difference with the students of both institutions. This has shown that supervision and assessment practices are one of the key factors in maintaining the quality of action research in the undergraduate programme. Clarke's (2006) opinion confirmed that teachers have worked more and more and have 
developed their educational area for constructive reflection by improving knowledge in their context, where they have undertaken research to improve their own work. Action research plays a key role in improving the skills of teachers in addressing the problem of the classroom and introducing them as professionals in the field (Whitehead, 2002). In addition, Jorge stated in his research that teachers have taken on the main role of formal instruction, which has shaped the research of teachers to complete professional teachers (Jorge, 2007). Action research could suggest the interests and values of the researchers in their own context, which would help design the project in the field of action research (Lydia, 2015).

\section{CONCLUSION}

This study concluded, after analysis and discussion, that perceptions and practices have a key role to play in promoting the quality of action research, where the research questions had shown that each Teacher Education Institution was little or no significant different from each other. They all follow the policies of the HEC, but were independently responsible for planning and setting the criteria as they could achieve the goal of the research project in a given time. The study also found out that the real scenario of teacher education in most of the institutions work best for academic sessions, most of which work only for the sake of degrees, could not accept the value of the research action. The challenges faced by student teachers are not knowledge and resources, but they are trying to achieve the objectives of the degree. At the end of the day, they need some awareness on action research and well-qualified staff to have knowledge of action research and its practices for the best academic session. There should be coordination between supervisors and student teachers, training and workshops for supervisors.

\section{RECOMMENDATIONS}

1. Teacher educators and research coordinators should play a key role in this field, working as mentors to develop interest, create a learning

Volume 1, Number 1 (Inaugural Edition)

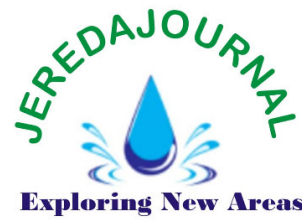

environment and make use technology to impact action research on prospective teachers.

2. It is recommended that the public universities need to facilitate affiliated colleges, assist and provide them with platforms of workshops and monthly meetings in some specific subjects.

3. It is noted that prospective teachers do not have resources such as internet, photocopier, printer and other materials for research work, so it is recommended that they be provided with sub-laboratories that meet 21 century well-equipped laboratories and resources for better education and results.

4. Interview with Teacher Educator Institutes also showed low knowledge, it is therefore recommended that MPhil or Ph.D. should be used to to teach in Teachers Education Institutions.

5. Teachers should be given incentives or appreciation for their support in conducting action research in schools.

\section{Conflicts of Interest}

The authors declare no conflict of interest.

\section{Disclaimer Statement}

We hereby declare that this paper is our own and autonomous work. All sources and aids used have been indicated as such. All texts either quoted directly or paraphrased have been indicated by in-text citations. Full bibliographic details are given in the reference list which also contains internet sources containing URL.

\section{Notes on Authors}

Nadia Parveen Thalho hails from Nasirabad (Larkana) Sindh. She had her primary school education at Primary Main School Nasirabad (1-5Grade), her secondary education was at Government Girls High School Nasirabad (6-10 Grade), Government Degree College (Grade 11-12). She had her M.A Hons Sociology at the Department of Sociology, University of Sindh Jamhoro Sindh and her M.Ed at $65 \mid \mathrm{P}$ a g e 
Faculty of Education, University of Sindh jamhoro, Sindh. Nadia just concluded her Mphil-Eduation at Iqra University Karach, i Pakistan. She is currently working as a teacher/ instructor/Lecturer at Government Elementary College of Education women Hyderabad Sindh.

Yakubu Doris Gomos is a graduate of Department of Special Education and Rehabilitation Sciences, University of Jos, Jos, Plateau State, Nigeria, where he bagged Bachelor in Education (Bed), Master in Education (Med). She is currently a lecturer and also pursuing her Doctoral degree in her alma mater in the Department of Special Education \& Rehabilitation Sciences, University of Jos, Jos. Nigeria. She is a member of many professional associations. Her research interests are in Hearing handicap, Reading, Sign Language Interpreting. She has attended conferences and published several articles in National and International Journals.

\section{Authorship and Level of Contribution}

The first author searched the literature, wrote and compiled the manuscript, while the second author brought the materials consulted together, reviewed it and analyzed the data collected for the study. Moreover, all the authors participated in the conduct of the study.

\section{REFERENCES}

Andrew, P. J. (2012). A short guide to action research. Pearson Education.

Auriacombe, C. J. (2015). Closing the gap between theory and practice with action research. https://repository.up.ac.za/handle/ 2263/58171

Bartlett, M. S. (1950). Tests of significance in factor analysis. https://doi.org/10.1111/j.20448317.1950.tb00285.x.

Biratu, S. (2016), Action research practices, challenges and prospects: The case of bole preparatory school. http://etd.aau.edu.et/bitstream/han dle/123456789/9711/Samuel\%20Bi ratu.pdf? sequence $=1$ \&isAllowed $=y$

Clarke, A. E. (2006). Teacher inquiry: What's old is new again! http://blogs.ubc.ca/stevemcg/files/ 2015/09/Clarke-Erickson-2006.-

Volume 1, Number 1 (Inaugural Edition)
Teacher-inquiry-Whats-old-is-newagain.pdf

Creswell, J. W. (2005). Educational research: Planning conducting and evaluating quantitative and qualitative research (4 Ed.). Pearson.

Cronbach, L. J. (1951). Coefficient alpha and the internal structure of tests. Journal of Psycho metrika, 16 (3), 97-334.

Darling-Hammond, L. (2006). Constructing 21 st-century teacher education. Journal of Teacher Education, 57(3), 300-314.

Disharoon, R. A. (2003). Action research toolkit arts education.

http://www.aemsedu.org/PDFs/Action Research Tool kit.pdf

Ferrance, E. (2000). Themes in education action research, (mafiadoc.com, Producer).

https://mafiadoc.com/themes-ineducation-action-

Guide Library. (2019). SPSS tutorials: Independent samples $t$ Test. https://libguides.library.kent.edu/sp ss/independentttest

Jorge, J. R. (2007). Teachers' conceptions of teacher-research and selfperceptions as enquiring practitioners-A longitudinal case study. Teaching and Teacher Education, 23 (4), 402-417.

Kaiser, H. F. (1974). An index of factor simplicity, Journal of Multivariate Behavioral Research, 39 (1), 31-36. https://www.statisticshowto.datasci encecentral.com/kaiser-meyerolkin/

Lankshear, C., \& Michele, K. (2004). A handbook for teacher research: From design to implementation (illustrated, reprint 1 ed) Open University Press.

Cronbach, L. J. (1951). Coefficient alpha and the internal structure of tests, Journal of Psycho metrika, 16(3), 97-334.

Leech, N. L., Barrett, K. C., \& Morgan, G. A. (2005). SPSS for intermediate statistics: Use and interpretation. https://psycnet.apa.org/record/200 4-18541-000.

Lydia, A. (2015). Action research for higher education practitioners: A practical guide. 
Journal of Educational Research in Developing Areas (JEREDA)

Vol. 1. Issue 1, Pp. 57-67, Inaugural Edition, 2020

http://www.jeredajournal.com

E-mail: info@jeredajournal.com

https://lydiaarnold.files. wordpress.c om/2015/02/action-researchintroductory-resource.pdf.

Maksimovic, J. (2010). Historical development of action research. Philosophy, Sociology, Psychology and History, 9 (1), 119 - 124. http://facta.junis.ni.ac.rs/pas/pas20 10/pas2010-10.pdf

Mahmood, N., \& Iqbal, Z. (2018). Challenges faced by prospective teachers during teaching. Journal of Bulletin of Education and Research, 40 (2), 113-136.

Mills, G. E. (2007). Action research: A guide for the teacher (5th ed.). Pearson.

https://files.pearsoned.de/inf/ext/9 781292054490.

National Education Policy. (2017). National Education Policy 2017-2025. Government of Pakistan Ministry of Federal Education and Professional Training Islamabad. http://www.moent.gov.pk/userfiles 1/file/National\%20Educaiton\%20Pol icy\%202017.pdf

Noddings, N. (2018). Philosophy of Education (4th Ed.). Routledge.

Noffke, S. E. (1997). Professional, personal and political dimensions of action research. Journal of Review of research in Education, 22 (1), 305343.

NPST. (2009). National professional standards of teachers, policy and planning wing ministry of education government of Pakistan Islamabad. http://unesco.org.pk/education/doc uments/step/National\%20Profession al\%20Standards\%20for\%20Teacher s\%20in\%20Pakistan.pdf.

Osborne, W. J., \& Ovrbay, A. (2004). The power of outliers (and why researchers should.

https://www.researchgate.net/profil e/Jason Osborne2/publication/2420 73851 The Power of Outliers and Why Researchers Should Always Check for Them/links/0c96053606 c3cb1b2f000000.pdf

Patrick, S., Boer, Christa, Lothar, S., \& Schwarte. (2018). Correlation coefficients appropriate use and interpretation. International Anesthesia Research Society, 126 (6), 1763-1768.

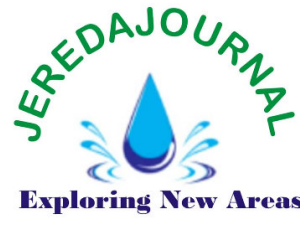

Saifulla, S., Sherzaman, A. A., Ali, S. S., Idrees, A., \& Zaman, S. (2013). Effect of reformed teaching practicum on profession development of B.Ed (Hons) prospective teachers. Journal of Bulletin of Education and Research, 35(2), 125-138.

Scheme of Studies. (2012). Scheme of studies associate degree in education in service.

http://hec.gov.pk/english/services/

universities/RevisedCurricula/Docu ments/2011-

2012/Education/ADEinService.pdf.

Steele, L. (2007). Accessible portfolios: Making it happen.

https://core.ac.uk/download/pdf/41 335669.pdf.

Whitehead, J. (2002). Action research: Principles and practice, $\left(2^{\text {nd }}\right.$ ed.). Routledge.

Yıldız, M., Geçikli, M., \& Yeşilyurt, S. (2016), Turkish prospective english teachers' reflections on teaching practice. Universal Journal of Educational Research, 4 (4), 696703.

Zeichner, K. M. (2003). Teacher research as professional development for P12 educators in the USA. Journal of Educational Action Research, 11(2), 301-326. 